\title{
NATIONAL BUREAU OF STANDARDS REPORT
}

6111

THERMAL AND SELF-IGNITION PROPERTIES

OF THREE SOLID PROPELLANTS

\author{
by \\ J. J. Loftus \\ and \\ D. Gross
}

\section{NBS}

U. S. DEPARTMENT OF COMMERCE NATIONAL BUREAU OF STANDARDS 


\section{THE NATIONAL BUREAU OF STANDARDS}

\section{Functions and Activities}

The functions of the National Bureau of Standards are set forth in the Act of Congress, March 3. 1901, as amended by Congress in Public Law 619, 1950. These include the development and maintenance of the national standards of measurement and the provision of ineans and methods for making measurements consistent with these standards; the determination of physical constants and properties of materials; the development of methods and instruments for testing materials, devices, and structures; advisory services to Government Agencies on scientific and technical problems; invention and development of devices to serve special needs of the Government; and the development of standard practices, codes, and specifications. 'The work includes basic and applied research, development, engineering, instrumentation, testing, evaluation, calibration scrvices, and various ronsultation and information services. A major portion of the Bureau's work is performed for other Government Agencies, particularly the Department of Defense and the Atomic Energy Conımission. The scope of activities is suggested by the listing of divisions and sections on the inside of the back cover.

\section{Reports and Publications}

The results of the Bureau's work take the form of either actual equipment and devices or publisherl papers and reports. Reports are issued to the sponsoring agency of a particular project or program. Published papers appear either in the Bureau's own series of publications or in the journals of professional and scientific societies. The Bureau itself publishes three monthly periodicals, available from the Government Printing (Office: The Journal of Research, which presents romplete papers reporting techniral investigations; the Technical News Bulletin, which presents summary and preliminary reports on work in progress; and Basic Radio Propagation Predictions, which provides data for determining the best frequencies to use for radio comm mnications throughout the world. There are also five series of nonperiodical publications: The Applied Mathematics Series, Circulars, Handbooks, Building Materials and Structures Reports, and Miscellaneous Publications.

Information on the Bureau's publications can be found in NBS Circular 460, Publications of the National Burean of Standards (\$1.25) and its Supplement (\$0.75), available from the Superintendent of Documents, Government Printing (Office, Washington 25, D. C.

Inquiries regarding the Bureau's reports should be addressed to the Office of Technical Information, National dureau of Standards, Washington 25, D. C. 


\section{NATIONAL BUREAU OF STANDARDS REPRT}

NBS PROJECT

NiBS MEPORT

$1000-30-4820$

August 11, 1958

6111

\section{THERMAL AND SELF-IGNITION PROPERTIES \\ OF THREE SOLID PROPELLANTS}

by

J. J. Loftus

and

D. Gross

for

Department of the Navy

Naval Ordnance Laboratory

White Oak

Ref. No. 60921/5089/58

MATIOHAL BUREAU OF Intended for use. within 10. additional eraituation listing of this Report, el the Office of the Directo however, by the Govern to reproduce additional

IMPORTANT KGTICE

Approved for public release by the Director of the National Institute of Standards and Technology (NIST) on October 9, 2015.

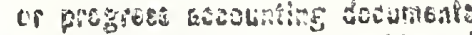

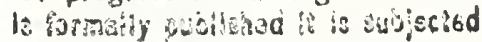

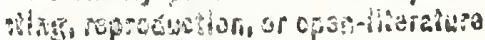
armission is cotalined in witing from i. C. Suct pormissica is not needeü. lceily prepared if that agancy wisheo

\section{NBS}

\section{U. S. DEPARTMENT OF COMHMEINES}


Thermal and Self-Ignition Properties

of Three Solid Propellants

J. J. Loftus and D. Gross

ABSTRACT

\begin{abstract}
Measurements have been made of the specific heat, thermal conductivity and kinetic properties of three solid propellants. Based upon these measurements, estimates are provided of the self-ignition hazard associated with the use and bulk storage of such propellants.
\end{abstract}

\title{
INTRODUCTION
}

An understanding of the mechanism of the thermal decomposition of explosives, propellants, and fuels requires knowledge of the kinetics of the reactions involved. One application of this knowledge is in the analysis of the selfignition hazard associated with the use or storage of these materials. With the present trend toward the design and use of large rocket propellant grains, basic information on the size limitations for storage of such propellants is important.

At the request of the Naval Ordnance Laboratory, letter dated 12/23/57, s/G. K. Hartman, determination of the thermal and kinetic properties of several solid propellants was initiated. Based upon an analysis of the self-heating reaction and the magnitude of these properties, an estimation may be made of the critical size and temperature conditions for self-ignition.

\section{MATERIALS}

The three solid propellant materials were furnished by the Naval Ordnance Laboratory in the shapes required for test and were identified as A, B and $\mathrm{C}$ in the chronological order of their receipt. 



\section{EXPERIMENTAL WORK}

A. Thermal Conductivity Measurements

For these measurements, a heat-flow meter type of thermal conductivity apparatus ${ }^{1}$ was used. In operation, two slabs each 10 by 10 by 1 -in., comprising a sample pair of the specimen under test are placed one on each side of a heatflow meter and then the faces of a hot plate and of a cold plate are brought together to make intimate contact with the specimens. At steady state, the heat flowing through the meter from the hot plate maintained at $32.8^{\circ} \mathrm{C}\left(91^{\circ} \mathrm{F}\right)$ to the cold plate maintained at $13.3^{\circ} \mathrm{C}\left(56^{\circ} \mathrm{F}\right)$ produces an emf proportional to the temperature gradient through the meter. The coefficient of thermal conductivity for each specimen was determined from the heat-flow meter output, the thickness of the specimen and the temperature drop in the specimen as measured by thermocouples. The heat-flow meter was calibrated by tests made on two materials of known conductivities as previously determined using a guarded hot plate (ASTM C 177-45). Two tests, one "forward" and one "reverse", were performed on propellants $A$ and $B$. Since only one 10 by 10 by $I-i n$. specimen of propellant $C$ was available for test, this propellant was tested in only one direction.

The results are summarized in Table 1.

Table 1. Thermal Conductivity Measurements Material Density

Mean

Temperature Thermal Conductivity $\mathrm{g} / \mathrm{cm}^{3}$ cal/sec-cm-deg C

$\begin{array}{lccll}\text { Propellant A } & 1.621 & 23.1 & \begin{array}{l}0.0005253 \\ 0.0005315\end{array} & 0.000527 \pm_{1} \% \\ \text { Propellant B } & 1.786 & 23.1 & \begin{array}{l}0.001322 \\ 0.001329\end{array} & 0.001326 \pm 0.5 \% \\ & & & & 0.001002 \pm_{1} \%\end{array}$


: 


\section{B. Specific Heat Measurements}

For these measurements, each propellant sample measured 1 by 2 by $2-1 / 2-i n$. To eliminate the possibility of interaction between the propellants and the water bath of the calorimeter, propellants $A$ and $B$ were sealed in individual plastic envelopes while propellant $C$ was spray-coated with a plastic film for test. The specific heats of the samples were measured by substituting them, separately, for $100 \mathrm{~g}$ of water in a calorimeter normally containing $600 \mathrm{~g}$, and measuring the energy equivalent of the calorimeter and contents electrically.. From the value obtained for the calorimeter with $600 \mathrm{~g}$ of water and the values obtained when the propellants were tested, the specific heats of the propeliants including their plastic envelopes were obtained. The specific heat of the propellant was determined using a value of $0.69 \mathrm{cal} / \mathrm{g}$-deg $C$ for, the specific heat of the plastic envelope. The specific heat of water was taken as $0.9992 \mathrm{cal} / \mathrm{g}$ at $22.5^{\circ} \mathrm{C}$. Measurements were made over a 3 to $4 \mathrm{deg} \mathrm{C}$ range between 20 and $25^{\circ} \mathrm{C}$. This method of measurement groups all the errors of measurement into the value obtained for the specific heat of the propellant. Two duplicate tests on the same sample were performed and the results are summarized in Table 2 .

Table 2. Specific Heat Measurements

\begin{tabular}{|c|c|c|c|c|c|}
\hline Material & $\begin{array}{c}\text { Sample } \\
\text { Weight } \\
\mathrm{g}\end{array}$ & $\begin{array}{c}\text { Envelope } \\
\text { Weight } \\
\mathrm{g}\end{array}$ & $\begin{array}{l}\text { Temp. } \\
\text { Rise } \\
\text { deg C }\end{array}$ & $\begin{array}{l}\text { Mean } \\
\text { Temp. } \\
\circ \mathrm{C}\end{array}$ & $\begin{array}{c}\text { Specific } \\
\text { Heat } \\
\text { cal/g-deg C }\end{array}$ \\
\hline Propeliant A & 134.1903 & 1.8603 & $\begin{array}{l}3.337 \\
3 \cdot 325\end{array}$ & $\begin{array}{l}23 \cdot 2 \\
22 \cdot 3\end{array}$ & $\begin{array}{l}0.3906 \\
0.37310 .38 \pm 0.01\end{array}$ \\
\hline Propellant B & 145.5787 & 1.7949 & $\begin{array}{l}3.841 \\
3.500\end{array}$ & $\begin{array}{l}22.9 \\
23.0\end{array}$ & $\begin{array}{l}0.2827 \\
0.30260 .29 \pm 0.01\end{array}$ \\
\hline Propellant C & 140.9178 & $4.3152 *$ & $\begin{array}{l}3.163 \\
3.234\end{array}$ & $\begin{array}{l}23.4 \\
23.5\end{array}$ & $\begin{array}{l}0.3124 \\
0.2925\end{array}$ \\
\hline
\end{tabular}

*sprayed-on plastic film

C. Kinetic Measurements

For these measurements, two pre-cut wafers 2-in. in diameter by I-in. thick as furnished were placed together to form a cylindrical specimen 2-in. in diameter by 2-in. long. 
i 
The specimen was assembled and mounted within a furnace designed for self-heating studies.2 During the initial heating period, the thermostatically controlled furnace air temperature was gradually increased by small temperature intervals. At a temperature at which an indication of selfheating was obtained according to the signal from a differential thermopile, the control system was actuated to provide "adiabatic" or compensating temperature rise control. The differential thermopile was composed of four (4) $28 \mathrm{ga}$. ( $B$ \& S) chromel-alumel thermocouples in series to indicate the mean temperature difference between the specimen and the furnace atmosphere. The electrical signal from the differential thermopile was applied to an amplifier and servo control system so as to automatically compensate for any temperature rise within the specimen. Under these conditions, the

specimen temperature remains uniform throughout its mass and the heat generated within the body increases its temperature according to the relation:

$$
c \rho d T / d t=A \epsilon^{-E / R T}
$$

where $\mathrm{T}=$ absolute temperature, $\mathrm{K}$

$t=$ time, sec

$\rho=$ specimen density, $\mathrm{g} / \mathrm{cm}^{3}$

$c=$ specific heat, $\mathrm{cal} / \mathrm{g}-\mathrm{deg} \mathrm{C}$

$\mathrm{A}=$ heat generation coefficient, $\mathrm{cal} / \mathrm{sec}-\mathrm{cm}^{3}$

$\mathrm{E}=$ activation energy, $\mathrm{kcal} / \mathrm{mole}$

$\mathrm{R}=$ gas constant $=0.001987 \mathrm{kcal} / \mathrm{mole}-\mathrm{K}$

Continuous records, Figures 1, 2, and $3 *$, of the specimen and furnace air temperatures were obtained on an automatic recorder from the signals of $24 \mathrm{ga}$. (B \& S) chromel-alumel thermocouples. Measurements were made of the slope of the curve, $\mathrm{dT} / \mathrm{dt}$, at a number of temperatures over the self-heating range. By taking logarithms and plotting In dT/dt versus $1 / T$, the resultant line has a slope of $-\mathrm{E} / \mathrm{R}$, and intercepts the In dT/dt axis at $I$ in $\mathrm{A} / \mathrm{p}$ c. At least two tests for each propellant were performed and the results from one test for each propellant is shown in Figure 4 together with those from similar tests on nitrocellulose plastic, wood fiberboard and purified cotton linters.

*These records were only included in 5 copies of this report including those forwarded to the sponsor. 

The plotted points approximate straight lines very closely and show the rate of temperature rise due to self-heating for each material under negligible heat loss conditions. Within the range shown, the displacement of a line toward higher values of reciprocal temperature indicates self-heating at relatively lower temperatures. Comparative rates of selfheating at any temperature may be read directly from the graph as illustrated in Table 3.

Table 3. Comparative Rates of Self-Heating

Rate of self-heating, deg $\mathrm{C} / \mathrm{min}$

Material Temperature: $135^{\circ} \mathrm{C}$ Temperature: $209^{\circ} \mathrm{C}$ $(I / T=0.002450) \quad(I / T=0.002075)$

Propellant A 1.15 C

Propellant B

a 0.84

Propellant C 0.07 1.58

Nitrocellulose plastic

Wood fiberboard

Cotton linters
0.225

0.025

$2 \cdot 3$

$\mathrm{b}$

a. No appreciable self-heating until $190^{\circ} \mathrm{C}$ b. No appreciable self-heating until $180^{\circ} \mathrm{C}$ c. Specimen consumed

At $135^{\circ} \mathrm{C}$, propellant $A$ exhibited self-heating at a rate of $1.15 \mathrm{deg} \mathrm{C} / \mathrm{min}$, approximately 5 times that of nitrocellulose plastic and 50 times that of wood fiberboard, while propellant $B$ exhibited no appreciable self-heating at temperatures below $190^{\circ} \mathrm{C}$. At this same temperature, propellant C self-heated at a rate of $0.07 \mathrm{deg} \mathrm{C} / \mathrm{min}$. At $209^{\circ} \mathrm{C}$, propeliant $\mathrm{A}$ had been entirely consumed while propellant $B$ exhibited self-heating at a rate of $0.84 \mathrm{deg} \mathrm{C} / \mathrm{min}$, approximately $\mathrm{I} / 3$ that of wood fiberboard, and propellant $\mathrm{C}$ showed self-heating at a rate of $1.58 \mathrm{deg} \mathrm{C} / \mathrm{min}$, approximately $2 / 3$ that of wood fiberboard.

The values of the kinetic constants determined from the Iines in Figure 4 are listed in Table 4 for the applicable temperature ranges. 

Table 4. Kinetic Measurements

\begin{tabular}{|c|c|c|c|}
\hline Material & $\begin{array}{c}\text { Temperature } \\
\text { Ranges } \\
\text { C }\end{array}$ & $\begin{array}{l}\text { Activation } \\
\text { Energy E } \\
\text { kcal/mole }\end{array}$ & $\begin{array}{c}\text { Heat Generation } \\
\text { Coefficient } A \\
\text { cal/sec-cm }\end{array}$ \\
\hline
\end{tabular}

$\begin{array}{lrll}\text { Propeliant A } & 100-170 & 38.8 & 6.99 \times 10^{18} \\ \text { Propellant B } & 190-242 & 49.3 & 1.56 \times 10^{20} \\ \text { Propellant C } & 165-235 & 28.6 & 1.17 \times 10^{11} \\ \begin{array}{l}\text { Nitrocellulose } \\ \text { plastic }\end{array} & 134-169 & 42.0 & 2.43 \times 10^{19} \\ \text { Wood fiberboard } & 80-225 & 25.7 & 1.97 \times 10^{9} \\ \text { Cotton linters } & 180-260 & 34.5 & 5.30 \times 10^{11}\end{array}$

In the tests with propellants $B$ and $C$, a (nearly) constant temperature phase was observed at a temperature of about $240^{\circ} \mathrm{C}$. One possible explanation for this behavior would be a change in crystal structure occurring at this temperature.

In the tests with propellant $\mathrm{C}$, melting, softening or slumping of the propellant was observed at a temperature of about 140 to $160^{\circ} \mathrm{C}$. For the purposes of this analysis, it was assumed that the self-heating characteristics of the melted or slumped propellant were the same as those of the original solid.

Due to the unexpected behavior of propellant $C$ in the first few tests, a total of six tests were performed on specimens of this material and details of each of the tests are described below.

Test No. I

At an initial temperature setting of $114^{\circ} \mathrm{C}$, no appreciable self-heating was observed. After 38 minutes at this temperature, the temperature was raised to $156^{\circ} \mathrm{C}$. The specimen self-heated to $243^{\circ} \mathrm{C}$ in 65 minutes and remained at this temperature for about 2 minutes. After this short constant-temperature 

phase, very rapid combustion set in and the specimen was consumed. Based upon the data from this test, an activation energy of about $55 \mathrm{kcal} / \mathrm{mole}$ was computed.

Test No. 2

At an initial temperature setting of $141^{\circ} \mathrm{C}$, very little self-heating was observed. After 136 minutes at this temperature, the temperature was raised to $149^{\circ} \mathrm{C}$. The specimen self-heated to $162^{\circ} \mathrm{C}$ in 135 minutes at which time the adiabatic control operation and consequently the temperature measurements became erratic. It is interesting to note the behavior of this test specimen after the furnace temperature was increased in an effort to destroy the specimen. At a temperature of about $195^{\circ} \mathrm{C}$, this decision was reconsidered and the furnace heater was turned off. The specimen continued to heat reaching a temperature of $225^{\circ} \mathrm{C}$ before it started to cool. It had cooled down to $215^{\circ} \mathrm{C}$ and was continuing to cool when recording was discontinued for the day. It was found on the next day that the specimen had been consumed.

Test No. 3

After 25 minutes at a temperature setting of $82^{\circ} \mathrm{C}$, the furnace temperature was raised to $142^{\circ} \mathrm{C}$. After 15 minutes, the adiabatic control operation became erratic as in Test No. 2. The test was discontinued after approximately 90 minutes during which period the maximum recorded specimen temperature was $147^{\circ} \mathrm{C}$. The furnace and specimen were allowed to cool over night. Inspection of the furnace chamber the following day showed that the specimen had melted away from its holder and from the recording and controlling thermocouples and was found resolidified at the bottom of the furnace chamber.

On the basis of this finding, it was assumed that softening or melting had occurred in each of the previous tests. It is speculated that in Test No. 1 a small quantity of propellant material had remained in contact with the control thermopile to permitadiabatic control operation whereas in Test Nos. 2 and 3, complete separation had occurred. For all succeeding tests, the cylindrical propellant specimens were placed in a 2-in. diameter by 2-in. high stainless steel wire basket consisting of 40 mesh, 0.010 -in. diameter wires. This basket served to support the softened or melting propellant specimen in position during the selfheating : process. 

Test No. 4

From an initial temperature of $130^{\circ} \mathrm{C}$, the specimen selfheated to $238^{\circ} \mathrm{C}$ in about 15 hours. After a short pause at this temperature, very rapid combustion occurred and the specimen was consumed. The data on the rate of temperature rise versus reciprocal temperature for this test was best approximated by two straight lines yielding an activation energy of $38.1 \mathrm{kcal} / \mathrm{mole}$ for the temperature range 180 to $200^{\circ} \mathrm{C}$ and an activation energy of $19.9 \mathrm{kcal} / \mathrm{mole}$ for the temperature range 200 to $235^{\circ} \mathrm{C}$.

Test No. 5

From an initial temperature of $130^{\circ} \mathrm{C}$, the specimen selfheated to $238^{\circ} \mathrm{C}$ in about 12 hours. After a short delay at this temperature, very rapid combustion occurred and the specimen was consumed. Analysis of the data yielded an activation energy of $24.1 \mathrm{kcal} / \mathrm{mole}$ for this test.

Test No. 6

From an initial temperature of $131^{\circ} \mathrm{C}$, the specimen selfheated to $236^{\circ} \mathrm{C}$ in about 10 hours. Following the characteristic pause at almost constant temperature, very rapid combustion occurred and the specimen was consumed. The activation energy for this test was calculated as $28.6 \mathrm{kcal} / \mathrm{mole}$ and is the value reported in the tables.

\section{CALCULATION OF CRITICAL SIZE}

In order to estimate the critical size for ignition of a mass of self-heating material, the analysis presented by Enig, Shanks and Southworth 3 was used. This relates the half-thickness of a material of given thermal and kinetic properties with the temperatures at the center and the surface under critical steady-state conditions. This analysis has been applied to wood fiberboard and cotton linters and fair agreement with experimental results has been obtained. 4

The assumption was made that the kinetic properties measured over higher temperature ranges may be applied to the temperature range of practical interest for ordinary storage $\left(20-100^{\circ} \mathrm{C}\right)$. It was further assumed that the measured thermal properties may be applied over the whole 

temperature range. Critical radius determinations for a sphere have been made for each propellant and for three other common materials, and these are listed in Table 5 and shown graphically in Figure 5. It may be noted from the tables in reference 3 that for a given surface temperature, the critical radius for a cylinder and the critical half thickness for a semiinfinite slab are given very closely by $0.775 \mathrm{Bc}_{\mathrm{c}}$ and $0.514 \mathrm{~B}_{\mathrm{C}}$ respectively, where $B_{c}$ is the critical radius for the sphere.

Table 5. Critical Size Calculations

Material

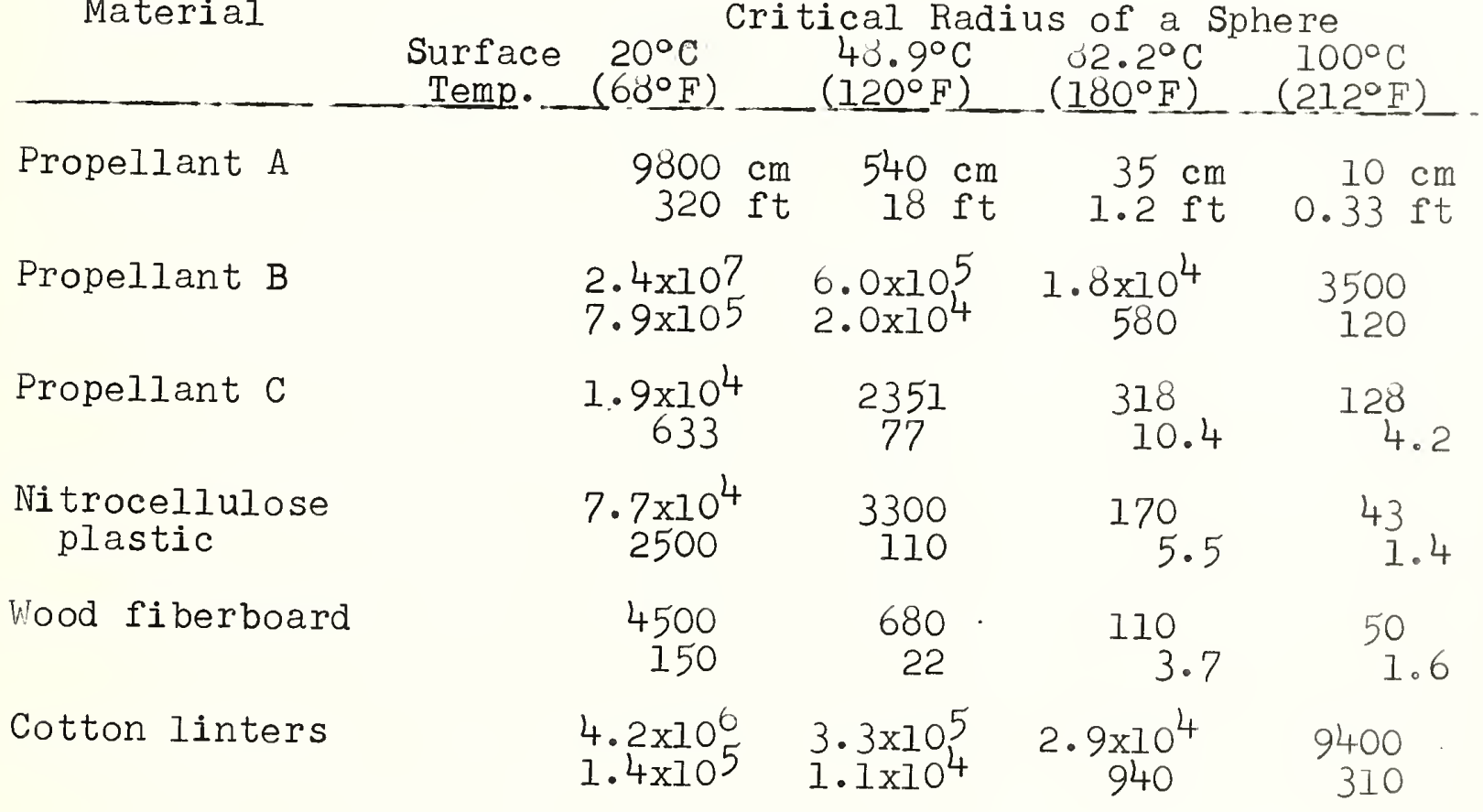

\section{SUMMARY}

Measurements of the specific heat, thermal conductivity and kinetic properties of 3 propellants have been made.

In the self-heating experiments, propellant A self-heated from an initial temperature of $100^{\circ} \mathrm{C}$ to a temperature of $170^{\circ} \mathrm{C}$ in 10 hours. At this temperature, very rapid combustion occurred and the sample was consumed. The activation energy for propellant A over this temperature range was $38.8 \mathrm{kcal} / \mathrm{mole}$. Propellant $B$ seli-heated in $2-1 / 2$ hours from an initial 

temperature of $190^{\circ} \mathrm{C}$ to a temperature of $242^{\circ} \mathrm{C}$, at which temperature very rapid combustion occurred and the sample was consumed. The activation energy of propellant B over this temperature range was $49.3 \mathrm{kcal} / \mathrm{mole}$. Propellant C self-heated in 10 hours from an initial temperature of $131^{\circ} \mathrm{C}$ to a temperature of $236^{\circ} \mathrm{C}$ at which temperature very rapid combustion occurred and the sample was consumed. The activation energy of propellant $\mathrm{C}$ over this temperature range was $28.6 \mathrm{kcal} / \mathrm{mole}$.

A comparison of critical radius determinations, under the given assumptions, is presented in Table 5 and Figure 5 . Size limitations on the storage of bulk quantities of propellant A, propellant C and nitrocellulose plastic, and careful control of temperature and ventilation conditions seem justified on the basis of these calculations. Although wood fiberboard is not normally considered a storage hazard at temperatures up to $60^{\circ} \mathrm{C}\left(140^{\circ} \mathrm{F}\right)$, it has been known to selfheat to ignition when stacked hot after drying during the manufacturing process. Propellant B does not appear likely to present any storage hazard with respect to self-ignition at ordinary storage temperatures. 


\section{REFERENCES}

1. Lang, D. L., "A Quick Thermal Conductivity Test on Insulating Materials," ASTM Bul. No. 216, pp. 58-60, Sept. 1956.

2. Raskin, W. H. and Robertson, A. F., "An Adiabatic Apparatus for the Study of Self-Heating of Poorly Conducting Materials", Rev. Sci. Inst. 25, pp. 541-544, June 1954.

3. Enig, J. W., Shanks, D. and Southworth, R. W., "The Numerical Solution of the Heat Conduction Equation Occurring in the Theory of The rmal Explosions", NAVORD Report 4377 ( 1956 ).

4. Gross, D. and Robertson, A. F., "Self-Ignition Temperatures of Materials from Kinetic Reaction Data", to be published. 
$\rightarrow$ 


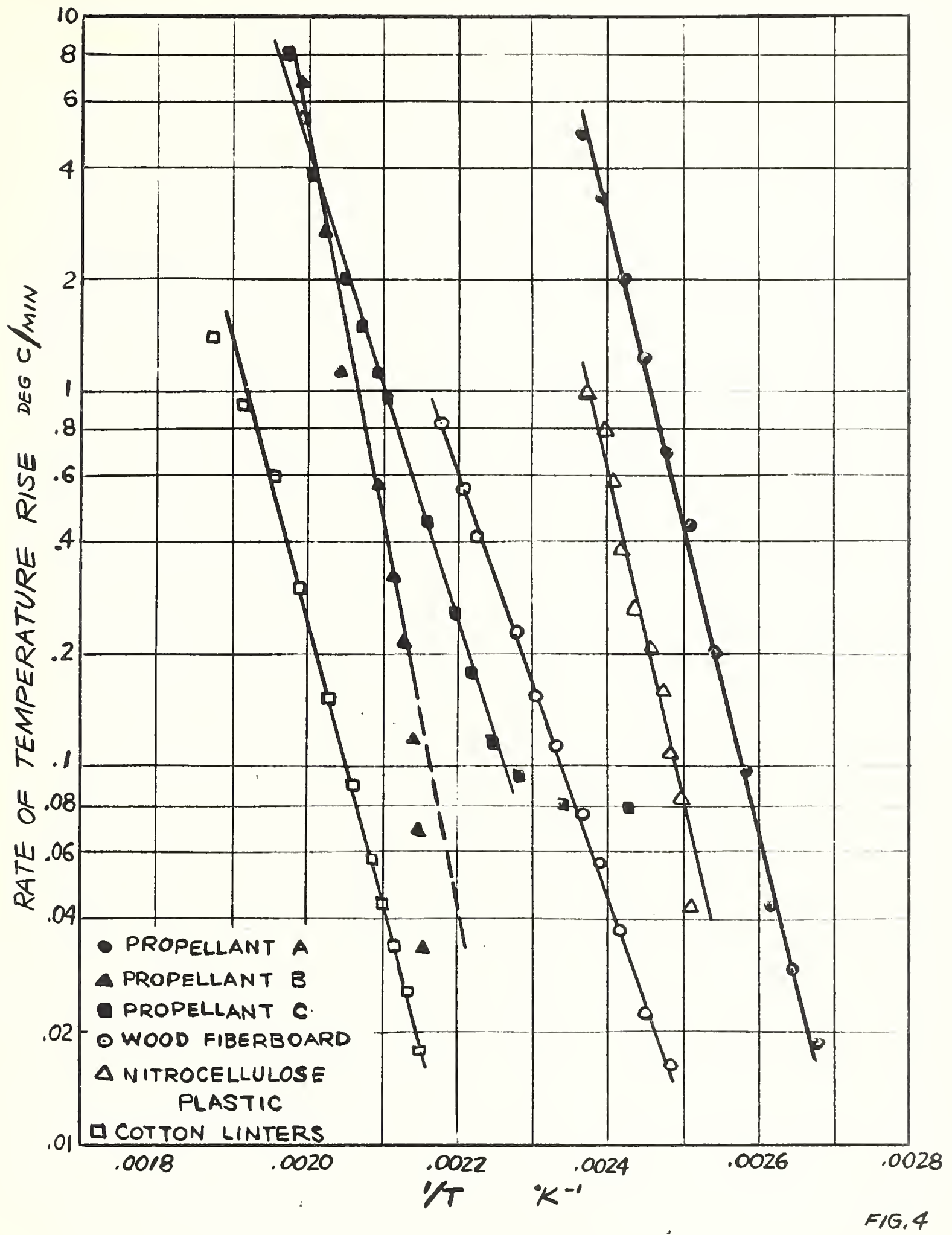


$w$

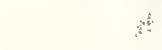

+4 


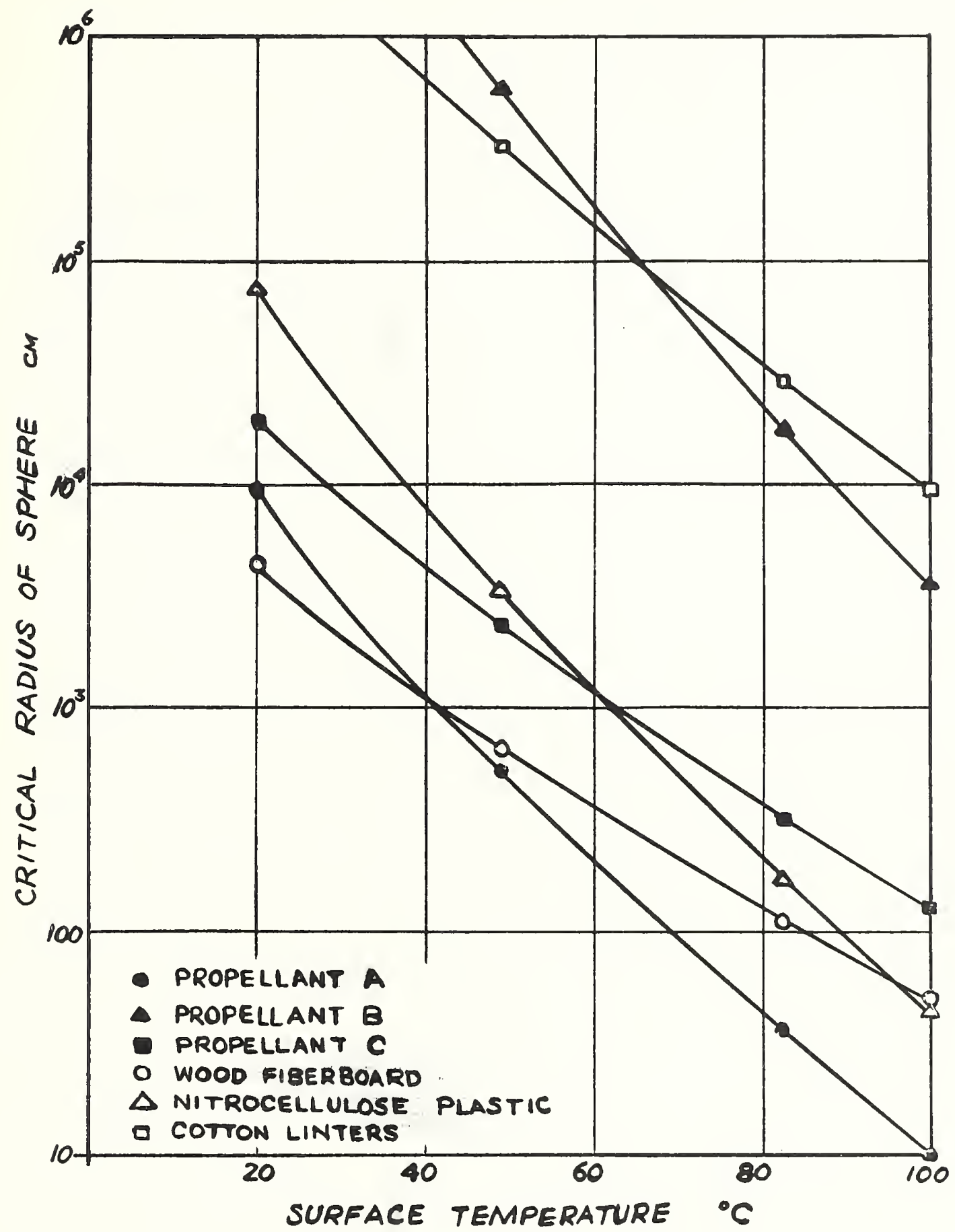

FIG. 5 
$x^{7}$

$x$

$: 3$

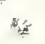

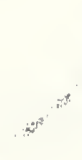

tr 
U. S. DEPARTMENT OF COMMERCE

Sinclair Weeks, Secretury

NATIONAL BUREAU OF STANDARDS

A. V. Astin, Director

\section{THE NATIONAL BUREAU OF STANDARDS}

The scope of activities of the National Bureau of Standards at its headquarters in Washington, D. C., and its major laboratories in Bonlder, Colo., is suggested in the following listing of the divisions and sections engaged in technical work. In general, each section carries out specialized research, development, and engineering in the field indicated by its title. A brief description of the activities, and of the resultant publications, appears on the inside front cover.

\section{WASHINGTON, D. C.}

Electricity and Electronics. Resistance and Reactance. Electron Devices. Electrical Instruments. Magnetic Measurements. Dielectrics. Engineering Electronics. Electronic Instrumentation. Electrochemistry.

Optics and Metrology. Photometry and Colorimetry. Optical Instruments. Photographic Technology. Length. Engineering Metrology.

Heat. Temperature Physics. Thermodynamics. Cryogenic Physics. Rheology. Engine Fuels. Free Radicals Research.

Atomic and Radiation Physics. Spectroscopy. Radiometry. Mass Spectrometry. Solid State Physics. Electron P'hysics. Atonic Physics. Neutron Pliysics. Nuclear Physics. Radioactiv. ity. X-rays. Betatron. Nucleonic Instrumentation. Radiological Equipnent.

Chemistry. Organic Coatings. Surface Chemistry. Organic Chemistry. Analytical Chemistry. Inorganic Cliemistry. Electrodeposition. Molecular Structure and Properties of Gases. Physical Chenistry. Thermochemistry. Spectrochemistry. Pure Substances.

Mechanics. Sound. Mechanical Instruments. Fluid Mechanics. Engineering Mechanics. Mass and Scale. Capacity, Density, and Fluid Meters. Combustion Controls.

Organic and Fibrous Materials. Rubber. Textiles. Paper. Leather. Testing and Specifications. Polymer Structure. Plastics. Dental Researcli.

Metallurgy. Thermal Metallurgy. Chenical Metallurgy. Mechanical Metallnrgy. Corrosion. Metal Physics.

Mineral Products. Engineering Ceramics. Glass. Refractories. Enameled Metals. Concret. ing Materials. Constitution and Microstructure.

Building Technology. Structural Engineering. Fire Protection. Air Conditioning, Heating, and Refrigeration. Floor, Roof, and Wall Coverings. Codes and Safety Standards. Heat Transfer.

Applied Mathematics. Numerical Analysis. Computation. Statistical Engineering. Mathenatical Physics.

Data Processing Systems. SEAC Engineering Group. Components and Techniques. Digital Circuitry. Digital Systenıs. Analog Systems. Application Engineering.

- Office of Basic Instrumentation.

- Office of Weights and Measures.

\section{BOULDER, COLORADO}

Cryogenic Engineering. Cryogenic Eqquipment. Cryogenic Processes. Properties of Materials. Gas Liquef action.

Radio Propagation Physics. Upper Atmosphere Research. Ionospherie Research. Regular Propagation Services. Sun-Earth Relationships. VHF Research.

Radio Propagation Engineering. Data Rednction Instrumentation. Modulation Systems. Navigation Systems. Ranlio Noise. 'I'ropospheric Measuremente. Tropospheric Analysis. Radio Systems Application Engineering. Radio Meteorology.

Radio Standardis. High Frequency Flectrical Standards. Radio Broadcast Service. High Frequency Impedance Standards. Calibrition Center. Microwave Physics. Microwave Circuit Standards. 
